International Journal of Child, Youth and Family Studies (2015) 6(2): 295-307

\title{
PARAMETERS OF PUBLIC POLICY CHANGE
}

\section{Toba Bryant}

\begin{abstract}
Research has identified a wide range of factors that influence the health of children and their health as adults. Key among these are early childhood conditions, care, and education, housing security and income security. A number of indicators have been developed to measure the health of children such as the incidences of infant mortality and low birth weight. In international comparisons with other rich countries, Canada ranks poorly. These health outcomes are not inevitable but are shaped by the quality and distribution of a wide range of social determinants. Public policies shape access to and quality of the social determinants of children's health (SDCH). Because the SDCH are amenable to public policy, it is important to understand public policy and the public policy development process in order to promote policy change. Yet few health practitioners who work with children consider or understand how the public policy development process works. This article examines three models of public policy development: pluralism, policy paradigms, and political economy. It will be argued that of the three models, political economy, with its focus on the role of political ideology and power distribution, provides the most compelling explanation of the public policy development process and provides means to bring about policy change to improve the health of children.
\end{abstract}

Keywords: public policy, social determinants of health, political economy, pluralism, policy paradigms

Toba Bryant, Ph.D. is an Assistant Professor at the Faculty of Health Sciences, University of Ontario Institute of Technology, 2000 Simcoe Street North, Oshawa, Ontario, Canada, L1H 7K4. Telephone: (905) 721-8668, ext. 2697. E-mail: toba.bryant@uoit.ca 
International Journal of Child, Youth and Family Studies (2015) 6(2): 295-307

Multiple factors influence children's health and well-being. Indeed, much research shows that conditions of early life influence health throughout the lifespan (Bartley, Blane, \& Montgomery, 1997; Ben-Shlomo \& Kuh, 2002 ; Benzeval, Dilnot, Judge, \& Taylor, 2001; Hertzman, 2001). This special issue highlights a number of these factors. In particular, the social determinants of children's health (SDCH) - housing security, income security, education and care, among others - that significantly shape the health of children and their health as adults.

Many indicators of children's health have been developed to compare nations' efforts to improve children's health. In these comparisons, Canada ranks below other rich nations (Howlett, Ramesh, \& Perl, 2009; Organisation for Economic Co-operation and Development, 2011, 2013). As two examples, Canada's infant mortality is almost 5/1,000 live births, with a rank of 27th among member countries of the Organisation for Economic Co-operation and Development (OECD) and its low birth weight rate of 6.2/100 gives it a rank of 13th. Canadian research shows that while the incidence of infant mortality and low birth weight is highest in low-income urban neighbourhoods as compared to higher income urban neighbourhoods in Canada, even in these wealthy areas rates are higher than for children in many other developed countries (Raphael, 2010).

These poor health outcomes for children are not inevitable. Rather, the health of children is tied to the quality and distribution of a wide range of SDCH in Canada and other countries. These SDCH include household income, housing quality, food security, and other resources that are available to families. All of these factors are influenced by public policy. Changes to the SDCH through public policy can influence - increase or reduce - these and other SDCH.

Few child health practitioners consider - or understand - how politics and the public policy development process shape children's health. Biomedical understandings of health continue to dominate public policy discourses concerning the health of populations. In addition, medical, nursing, and allied health professions training tends to have little instruction on public policy and how such policy shapes health. This contributes to a narrow emphasis on clinical health care by professions that usually precludes consideration of the broader determinants of the health of populations in general and children in particular.

A similar situation exists for those concerned with promoting child health through social work and psychology-related activities. Health is seen as being a characteristic of individuals, which can be influenced through clinical and community practice. There is a need to move the discussion of children's health to a higher level that focuses on how public policy shapes the $\mathrm{SDCH}$. The public policy literature provides a broad range of models that can be used to analyse the prospects for improving the SDCH. Such an analysis also provides clues as to how these issues can be moved onto the public policy agenda to create positive conditions for children's health (Mintrom \& Vergari, 1996). Yet, these models are rarely considered in discussions of how to bring about public policy change to improve children's health.

This article will explore the potential contributions and limitations of three key models of the public policy process: pluralism, policy paradigms, and political economy. The analysis will consider how they can be applied to bring about policy change to improve the SDCH. Pluralism 
International Journal of Child, Youth and Family Studies (2015) 6(2): 295-307

is concerned with the activity of interest groups as they try to shape public policy. Policy paradigms examines the role of knowledge in shaping different types of public policy. Political economy considers politics and economics as shaping public policy.

Each model represents a different level of analysis. It will be argued that of the three models, political economy offers the most cogent analysis of the conditions and factors that influence children's health and offers the best prospects for policy change to improve the health and well-being of children. At the same time it should prove useful for reducing the profound health inequalities that exist among children in Canada and elsewhere (Raphael, 2015).

\section{Public Policy and Public Policy Change as Determinants of Children's Health}

This special issue highlights some of the diverse factors that influence children's health. The articles in this issue of the International Journal of Child, Youth and Family Studies especially illustrate the importance of public policy in influencing children's health and I mention just three of these. Petrie (2015) shows how the increasing marketization and commodification of children and youth in the United Kingdom and in other wealthy countries has led to increased poverty and food insecurity for households with children. This has occurred as a result of the encroachment of the market economy into public services such that children and youth essentially become commodified themselves. These changes have material implications for their health and well-being. For example, daycare in most countries has become increasingly subject to market forces and is therefore not available to modest and low-income households.

Albanese and Rauhala (2015) argue that children, mothers, and child care providers tend to be missing from public policy discussions about daycare. Yet, high quality child care is critical to healthy child development and children's readiness to learn when they begin school. Rattle (2015) talks about the planning process and how it can neglect the health impacts of such developments upon children. What do models of policy change say about moving these issues onto the public policy agenda?

Yet, public policy discussion of children's health is dominated by issues focused on health care. Other dimensions of health - such as SDCH and reducing health inequalities among children - are seldom considered. Some of this may be attributable to the lack of awareness of practitioners - similar to the situation amongst most Canadians -- concerned with children's health about public policy and its role in shaping children's health outcomes. Practitioners also tend to be unaware of the importance of politics and how political ideology shapes public policy decisions made by governments (see Raphael, 2015).

Public policy theories can provide insights into the public policy development process and the factors affecting the public policy process. These include the role of politics and political ideology and how they influence public policy outcomes. These insights can be applied to bring about policy change to improve the SDCH. But what exactly is public policy and why is it important for understanding the SDCH?

Public policy is a plan or procedure for action or inaction by government to address a problem or related set of problems (Pal, 2006). Public policies are based on a set of values about 
appropriate goals and beliefs about how best to achieve those aims. Policies are also considered guides for action or inaction. Deciding not to take action is also a public policy decision. It retains the status quo rather than bringing about change on an identified issue. Decisions to act or not are embedded in the ideological commitments of the government of the day. Their ideological beliefs and values determine which issues they will prioritize and the policy instruments that will be used.

The literature identifies a wide range of factors that can influence whether a government decides to act or not act to address a problem (Howlett et al., 2009). These factors include previous policy decisions in a given policy area, external factors such as international crises (e.g., financial crises or wars), pressure from civil society organizations or movements, or demographic and other changes in a population. Demographic or other population shifts are especially important and can lead to the identification of necessary new services or programs to meet health and social needs in a community. For example, identifying a growing population of preschool children may lead government to develop programs and services for early childhood education and care, such as day care, full-day kindergarten, and establishing neighbourhood paediatric clinics. Similarly, an increased incidence of childhood diseases for which vaccines were available (e.g., measles or chicken pox), could inspire a government to implement a vaccination program to protect children from these diseases.

Health issues are complex and a government's decision to take action - or not - is fundamentally shaped by its ideological commitments. Ideological commitments are ideas and beliefs about the type of problems that will be addressed and the policy solutions that will be devised to mediate identified issues. This usually centres on whether government or a private agency will provide a service or program. This is the essence of the public versus privatization debate that so frequently dominates Canadian public policy discussions (Council of Canadians, 2007).

Public policy process models can provide lenses by which to understand and explain different elements of the public policy process and motivations for governments' action or inaction. Most models of public policy also consider policy change, but policy change represents a particular focus in the political science literature (Mintrom \& Vergari, 1996). Policy change usually signifies a new course of action to address an issue identified by government and/or others as having negative outcomes for a particular population or the population as a whole. Not all public policy models are concerned with the impact of politics and political ideology in shaping policy change outcomes.

An important distinction among models of public policy change is that between consensus models of public policy and conflict models (Brooks \& Miljan, 2003). Consensus models conceive the policy-making process as a rational process by which various interest groups compete to influence a more or less neutral State to implement specific forms of public policy. In contrast, conflict models of public policy-making emphasize the role of political ideology and power in shaping public policy decisions (Coburn, 2010). These models explicitly consider how public policy creates various forms of inequality as a result of differing balances of power among the State, the market, and civil society in the public policy process (see Raphael, 2015). 
International Journal of Child, Youth and Family Studies (2015) 6(2): 295-307

\section{Models of Public Policy Change}

\section{Pluralism}

Pluralism is one of the dominant policy approaches to examining middle ranges of public policy in North America. The model was developed in the United States in the early 20th century (Howlett et al., 2009). It is a consensus model of policy change in that it focuses on the competition among interest groups and their activities as significant influences on a more or less neutral State's making of public policy. Interest groups are therefore the key unit of analysis in pluralism. It conceives society as consisting of a plurality of interest groups. Since the complexity of governance in modern society precludes direct participation by individual citizens, citizens join groups to advocate for their concerns. An early pluralist theorist argued that, "society is nothing other than the complex of the groups that compose it" (Bentley, as cited in Howlett et al., 2009). Individuals can belong to a large number of interest groups, which can cooperate with other groups to advocate on a particular issue and specific public policy changes (Howlett et al., 2009). For example, a parent may belong to an organization that advocates for a national child care program, to an organization that advocates for more responsive health care, as well as to one that call for fairer taxation.

Pluralism considers politics as the process by which competing interests and groups come together to achieve agreed-upon public policy outcomes. The role of the State is to mediate the competition among diverse interest groups and to then make a public policy decision. Critics identify the implicit assumption that all groups, regardless of their policy positions, will have their voices heard by government (McLennan, 1989). Pluralists deny that this is the case, and claim that they recognize that interest groups vary in their influence which depend on the financial and other resources available to them (Howlett et al., 2009). The concept of inequality in influence and power is underdeveloped in pluralism. There remains a pervasive sense that all citizens and citizen organizations can present their ideas to government and receive a fair hearing (McLennan, 1989).

For example, it is believed that groups with ideas for improving children's health can expect that government will hear and may act on their recommendations. In addition, implicit in this model is a neutral and benevolent State that arbitrates among competing interests. The State is considered to weigh all the evidence it receives - through a rational process - and arrives at a decision to benefit the entire community.

Previous research has identified that governments tend to filter out views that differ from their own (Bryant, 2003, 2004). Indeed, governments' decisions are very much shaped by their ideological commitments and the politics of the moment. As a result, governments are not always motivated to address the needs of marginalized populations and this is especially the case in regard to issues that include the SDCH (Bryant, 2010). 
International Journal of Child, Youth and Family Studies (2015) 6(2): 295-307

\section{Policy Paradigms}

The policy paradigms model is one of a family of policy change models referred to as learning models. These models posit that governments learn as they adjust policy goals or methods in response to previous experience and/or new information about an issue (Hall, 1993). Learning is frequently associated with past policy experiences. A primary aim of the policy paradigms model is to identify different patterns of policy change and the learning process associated with each policy change pattern (Hall, 1993). The policy paradigms model considers how the role of new knowledge can lead to incremental change or radical policy change that involves a significant shift in policy goals and objectives. The model focuses on the role of experts such as policy analysts inside and outside government and the knowledge and expertise they bring to the public policy process.

A paradigm refers to the framework of ideas and standards within which policy-makers work (Anderson, 1978). This framework identifies policy goals, the type of instruments to be used to achieve policy goals, and the type of problems that can and will be addressed by government (Hall, 1993). In short, a paradigm is a world view that guides action, in this case in the public policy arena, and can result in particular sets of outcomes or approaches to addressing social and health issues.

Central to the paradigms model is the typology of policy change consisting of three orders (Hall, 1993). First-order change refers to routine or minor policy changes such as increasing the number of neighbourhood after-hours paediatric clinics to complement regular health care services. Second-order change refers to a change in policy instruments to achieve a policy goal. For example, in an effort to deter youth from taking up smoking, a municipal government might develop public service announcements (PSAs) warning about the negative impact of tobacco products on health. The intention of such PSAs is to encourage youth to voluntarily decide not to smoke. If evidence shows that this voluntary measure has not worked, a government may opt to raise taxes on tobacco products as an involuntary measure to change their behaviour (Hall, 1993). Studies have found that youth are price-sensitive and that tax measures can be effective in discouraging smoking and may even contribute to smoking cessation (Ding, 2003; Thomas et al., 2008).

Neither first-order nor second-order change involves change in the overall goals or objectives of a policy area. The overall goals and objectives of a policy area remain the same. Both patterns of policy change involve incremental or minor changes to public policy.

Third-order change refers to radical policy change in which the overall policy goals and objectives change, as does the discourse related to the "received paradigm" (Hall, 1993). It is paradigmatic change that involves redefining the central issues of a public policy area. For example, the health policy paradigm could shift from a biomedical approach to a SDCH approach to children's health, which may involve shifting the broad dimensions of public policy. This could involve changing the parameters by which workplaces operate such as promoting inter-sectoral bargaining, easing the means by which workplaces can be unionized, or requiring the provision of benefits to part-time employees. In other words, change occurs in the instrument settings, the policy instruments to be used, and in the policy goals and objectives. Another 
example of paradigmatic change would be a shift from allowing privatized social and health service provision to one requiring the State to provide services. The formation of the welfare state in advanced political economies such as Canada after the Second World War signified a shift from residual social provision to significant State financing and provision of social and health services, and in the economy (Teeple, 2000).

The shift from one paradigm to another occurs can be a result of recognition of growing anomalies related to the received or dominant policy paradigm's ability to meet needs. Such a perception can necessitate a shift to a new policy paradigm. Hall argues that the shift to a new paradigm is driven by politics in that governments recognize a need to respond to these needs (Hall, 1993). Governments may experiment with differing policies, but usually it is outright policy failures that contribute to a shift in a policy paradigm.

Hall focuses on the role of experts and expert knowledge to the exclusion of other important actors and groups who attempt to influence the public policy process. Hall's policy paradigms approach is also a rational model of policy change. His model as initially presented does not sufficiently consider how politics leads to policy shifts (Bryant, 2013). The role of politics in the model appears to be limited to politicians deciding which policy paradigm will prevail in a debate between the dominant and new paradigms. This decision is based on the merits or weight of the scientific evidence supporting each paradigm.

The policy paradigms model is also a middle-level model in that it is concerned with the role institutions play in structuring public policy change. This means that institutions can impede policy change in that already established public policy paths will tend to be followed. This tendency is termed path dependency in which public policy set at an earlier point in time tends to influence future public policies (Pierson, 2000). To overcome such inertia requires not only evidence of the limitation of established public policy but also the means of impressing these arguments upon policy-makers.

In a recent article, Hall addresses some of the limitations of his model as initially articulated (Hall, 2013). He notes that the impetus for the shift to neo-liberal policies in the 1980s was the occurrence of the oil crisis of 1971, which led to increased unemployment and inflation in most developed economies. This in itself did not lead to public policy change such as the shift to market-driven economic paradigms. Rather these developments were buttressed by coordinated attacks by the corporate sector on State intervention - through regulation and redistribution - in the economy. As a result, deregulation and privatization were enabled as were declines in trade union power through government legislation.

The explicit recognition of the role that power and influence can play in pubic policymaking are more consistent with the concerns of political economy and provide the basis for a structural analysis of politics and political ideology in shaping policy change outcomes. Nevertheless, Hall continues to believe that the public policy development process is essentially rational and based on considered evaluations of both old and new knowledge and previous public policy experience. The political economy model, however, argues that important public policy decisions are driven more by the raw politics of power and how these interact with the ideological commitments of the government of the day. 
International Journal of Child, Youth and Family Studies (2015) 6(2): 295-307

\section{Political Economy}

Political economy is primarily concerned with how political ideology and power operate to shape the distribution of social and economic resources in a society (Armstrong, Armstrong, \& Coburn, 2001). A key component of this perspective is that politics and economics are closely related and influence public policy development (Coburn, 2004; Esping-Andersen, 1990). Esping-Andersen's welfare state typology exemplifies a political economy approach. It considers ideas and institutions - and public policy that emanate from these - as stemming from societal arrangements that are powerfully shaped by historical traditions. The primary features of welfare regimes are the extent to which the State intervenes in the economy to ensure equity in the distribution of material and social resources to citizens, and the role of the State, the market, and the family in economic and social provision. This approach conceives politics and economics as fundamentally related.

To a large degree, the State's role is strongly shaped by the degree of class mobilization (Esping-Andersen, 1990). This occurs because the loyalties of the working and middle classes directly shape the forms by which the economic and political systems function. The different loyalties shape the formation and maintenance of welfare state regimes. Esping-Andersen distinguishes between Social Democratic, Conservative, and Liberal welfare states, which helps explain public policy development on the social determinants of health in the post-World War II era. These different welfare state clusters are not inevitable, but have been shaped and moulded by ideologies of governments that are informed by the politics of political parties.

Social Democratic regimes provide the most generous and comprehensive health and social benefits to citizens (Esping-Andersen, 1990). This includes comprehensive public health care, access to unemployment insurance during periods of unemployment, job retraining for workers who have lost their jobs, and national day care programs, among others. It emphasizes State provision of social and economic benefits, and equality and universality in the provision of social and economic services and programs. For example, day care is equally available to all families with preschool children regardless of family income. The State is a key institution in these regimes. Examples of Social Democratic regimes are the Nordic countries: Denmark, Finland, Norway, and Sweden. These welfare states are considered highly redistributive and decommodified which means that citizens are less reliant on their incomes to access services and other necessities of life.

The Conservative welfare regime emphasizes the family as the primary source of support and the use of social insurance schemes that are usually tied to employment (Esping-Anderson, 1990). These welfare regimes are less decommodified compared to Social Democratic regimes and have higher tolerance for social stratification. Examples of Conservative regimes are Germany, France, Belgium, the Netherlands, and Switzerland.

Finally, Liberal regimes are the least decommodified welfare states (Esping-Andersen, 1990). Social and health services and programs tend to be targeted to specific populations identified as disadvantaged. The market is considered the most important institution, and freedom from government is an important guiding principle. Canada, the United States, the United Kingdom, Australia, and New Zealand are identified as Liberal welfare states. Liberal 
International Journal of Child, Youth and Family Studies (2015) 6(2): 295-307

welfare states have minimal decommodification. In terms of children's health and well-being, Canada provides a public-private mix of early childhood education and care. There is no national day care program, but a range of for-profit and non-profit day care programs. Subsidized day care spaces are available for low-income households, but so few of these are provided that it is difficult for parents, especially mothers, to acquire paid employment. Similarly, in some Canadian provinces, municipal public health departments provide dental care to children in lowincome households until 18 years, but not to the parents of these children. In contrast, free dental care is provided to children in the Social Democratic welfare states (Olsen, 2010).

Thus, a political economy approach presents a critical analysis that explains how some groups in society profit at the expense of others. It explicitly links neo-liberalism - an ideology of the market (Coburn, 2000; Teeple, 2000) that promotes free enterprise and freer trade between countries - to reductions in the welfare state during the 1980s. The value-added of a political economy approach - as compared to pluralism and policy paradigms - is a welfare state analysis which explicitly considers the impact of State intervention upon the SDCH.

Essentially, Esping-Andersen's identification of three types of welfare regimes assesses government intervention in the economy. Social Democratic welfare states are the engaged in managing the economy and providing generous State supports; Liberal welfare states much less so. Neo-liberalism, with its preference for the market as a key institution, has had its strongest effects in these liberal nations and have contributed to little action being taken on the SDCH (Raphael, 2014).

\section{Implications for Children's Health}

Of the three models of policy change, political economy provides the most compelling analysis of the current state of the SDCH in Canada. It emphasizes how political ideology that favours the market - and politics - shapes policy change outcomes. Governments become unwilling to create public policy that will redistribute economic and other resources to the most vulnerable in the service of the SDCH. Government also resists instituting programs that will impact the SDCH as these require increasing public revenues, a public policy approach at odds with the increasingly dominant neo-liberal political agenda of reducing taxes and minimizing governments’ role in the day-to-day lives of citizens (Coburn, 2004).

To counter these developments, children's health advocates must work strategically to achieve policy changes that will promote public health and knowledge of the SDCH. Traditional activities of meeting with cabinet ministers responsible for health policy and opposition parties must be maintained. These meetings will call for public policy initiatives that will improve child health and well-being and this is especially important for the most vulnerable households. Child health advocates must identify and promote public policy objectives of ensuring that resources and services such as early childhood care are available to all households with young children. These objectives must also include protecting housing and food security for all. In other words, it requires advocacy on the various dimensions that ensure child health and well-being from birth such that all children have the best possible start and opportunities to learn, thrive, and become contributing citizens. These activities will try to convince policy-makers to institute these public policy approaches (Wright, 1994). 
International Journal of Child, Youth and Family Studies (2015) 6(2): 295-307

The insights of the policy paradigms approach suggest that there will be resistance to public policy that substantially changes the goals and tools by which public policy is made. It will be necessary to provide evidence of the shortcoming of current public policy approaches and to present alternative approaches. Institutions such as government will resist such third-order change. Such resistance may also be countered by some of the methods suggested by the political economy approach.

The insights of the political economy approach suggest that these public policy advocacy activities attempting to change governmental approaches to public policy also require buttressing by powerful political and social movements that will force policy-makers to institute these public policy directions (Wright, 1994). This is especially the case in Liberal welfare states such as Canada where the business and corporate sectors traditionally have had greater influence on public policy-making than other societal sectors. These political and social movements such as advocates for a national child care program and Campaign 2000, which advocates for an end to child and family poverty, must create a groundswell of support for public policy that supports the SDCH. This can occur through building coalitions or supporting political parties that put forward such approaches (Brady, 2009). Such outcomes are certainly more difficult to achieve in Liberal welfare states than in other nations, but the history of Canada is replete with such successes in areas such as universal health care and public pensions (Rachlis, 2007).

Indeed, the opposition federal New Democratic Party (NDP) has announced its commitment to institute a universal affordable child care system in Canada upon its election in 2015 (New Democratic Party of Canada, 2014). It has also pledged to address the social determinants of health through public policy action (New Democratic Party of Canada, 2013). This will occur only if the public comes to support such initiatives and the NDP either achieves power or other political parties recognize this groundswell and also come to support such initiatives. Building support for these and other initiatives that will strengthen the SDCH and provoke governmental responses is what building political and social movements is all about.

\section{Conclusion}

Understanding the policy change process is critical to bringing about public policy that will improve and maintain the health and well-being of all children by strengthening the SDCH. This paper has examined pluralism, policy paradigms, and political economy for their insights into bringing about desired public policy change. Of the three models, policy paradigms and political economy draw our attention to the role of the political ideology of the government of the day and the influence of the business and market sector in shaping policy change outcomes. The practical implications of this assessment are that advocates for children's health must think strategically and become engaged in the political process. Such engagement appears to be necessary to influence the public policy change process in a direction and manner that will support children's health and well-being rather than threaten it. 
International Journal of Child, Youth and Family Studies (2015) 6(2): 295-307

\section{References}

Albanese, P., \& Rauhala, A. (2015). A decade of disconnection: Child care policies in changing economic times in the Canadian context. International Journal of Child, Youth and Family Studies, 6(2), 252-274.

Anderson, C. (1978). The logic of public problems: Evaluation in comparative policy research. In D. Ashford (Ed.), Comparing public policies (pp. 19-41). Beverley Hills, CA: Sage.

Armstrong, P., Armstrong, H., \& Coburn, D. (Eds.). (2001). Unhealthy times: The political economy of health and care in Canada. Toronto: Oxford University Press.

Bartley, M., Blane, D., \& Montgomery, S. (1997). Health and the life course: why safety nets matter. British Medical Journal, 314(7088), 1194-1196.

Ben-Shlomo, Y., \& Kuh, D. (2002). A life course approach to chronic disease epidemiology: conceptual models, empirical challenges and interdisciplinary perspectives. International Journal of Epidemiology, 31(2), 285-293. http://dx.doi.org/10.1093/ije/31.2.285

Benzeval, M., Dilnor, A., Judge, K., \& Taylor, J. (2001). Income and health over the lifecourse: Evidence and policy implications. In H. Graham (Ed.), Understanding health inequalities (pp. 96-112). Buckingham, UK: Open University Press.

Brady, D. (2009). Rich democracies, poor people: How politics explain poverty. New York: Oxford University Press. http://dx.doi.org/10.1093/acprof:oso/9780195385878.001.0001

Brooks, S., \& Miljan, L. (2003). Theories of public policy. In S. Brooks \& L. Miljan (Eds.), Public policy in Canada: An introduction (pp. 22-49). Toronto: Oxford University Press.

Bryant, T. (2003). A critical examination of the hospital restructuring process in Ontario, Canada. Health Policy, 64(2), 193-205. http://dx.doi.org/10.1016/s0168-8510(02)00157-4

Bryant, T. (2004). The role of political ideology in rental housing policy in Ontario. Housing Studies, 19(4), 635-651.

Bryant, T. (2010). Politics, public policy and health inequalities. In T. Bryant, D. Raphael, \& M. Rioux (Eds.), Staying alive: Critical perspectives on health, illness, and health care (2nd ed., pp. 239-265). Toronto: Canadian Scholars’ Press.

Bryant, T. (2013). Policy change and the social determinants of health. In C. Clavier \& E. de Leeuw (Eds.), Health promotion and the policy process (pp. 63-81). Oxford, UK: Oxford University Press. http://dx.doi.org/10.1093/acprof:oso/9780199658039.003.0004

Coburn, D. (2000). Income inequality, social cohesion and the health status of populations: The role of neo-liberalism. Social Science \& Medicine, 51(1), 135-146.

http://dx.doi.org/10.1016/s0277-9536(99)00445-1 
International Journal of Child, Youth and Family Studies (2015) 6(2): 295-307

Coburn, D. (2004). Beyond the income inequality hypothesis: Globalization, neo-liberalism, and health inequalities. Social Science \& Medicine, 58, 41-56. http://dx.doi.org/10.1016/s0277-9536(03)00159-x

Coburn, D. (2010). Health and health care: A political economy perspective. In T. Bryant, D. Raphael, \& M. Rioux (Eds.), Staying alive: Critical perspectives on health, illness, and health care (2nd ed., pp. 65-92). Toronto: Canadian Scholars’ Press.

Council of Canadians. (2007). Profit and public-private partnerships. Ottawa: Council of Canadians. Retrieved from http://www.profitsisnotthecure.ca/learn/P3s.html

Ding, A. (2003). Youth are more sensitive to price changes in cigarettes than adults. The Yale Journal of Biology and Medicine, 76(3), 115-124.

Esping-Andersen, G. (1990). The three worlds of welfare capitalism. Princeton, NJ: Princeton University Press.

Hall, P. (1993). Policy paradigms, social learning, and the state: The case of economic policymaking in Britain. Comparative Politics, 25(3), 275-296. http://dx.doi.org/10.2307/422246

Hall, P. A. (2013). Brother, can you paradigm? Governance, 26(2), 189-192. http://dx.doi.org/10.1111/gove.12031

Hertzman, C. (2001). Population health and child development: A view from Canada. In J. A. Auerbach \& B. Krinmgold (Eds.), Income, socioeconomic status, and health: Exploring the relationships (pp. 44-55). Washington, DC: National Policy Association.

Howlett, M., Ramesh, M., \& Perl, A. (2009). Studying public policy: Policy cycles and policy subsystems. Don Mills, ON: Oxford University Press.

McLennan, G. (1989). Marxism, pluralism and beyond: Classic debates and new departures. Cambridge, UK: Polity Press.

Mintrom, M., \& Vergari, S. (1996). Advocacy coalitions, policy entrepreneurs, and policy change. Policy Studies Journal, 24(3), 420-434. http://dx.doi.org/10.1111/j.1541-0072.1996.tb01638.x

New Democratic Party of Canada. (2013). Prevention is better than cure. Retrieved from http://www.ndp.ca/prevention-better-cure.

New Democratic Party of Canada. (2014). Affordable childcare. Retrieved from http://www.ndp.ca/childcare.

Olsen, G. (2010). Power and inequality: A comparative introduction. Toronto: Oxford University Press.

Organisation for Economic Cooperation and Development. (2011). Health at a glance 2011: OECD indicators. Paris: Author. 
International Journal of Child, Youth and Family Studies (2015) 6(2): 295-307

Organisation for Economic Cooperation and Development. (2013). Health at a glance 2013: OECD indicators. Paris: Author.

Pal, L. (2006). Beyond policy analysis: Public issue management in turbulent times. Toronto: Nelson.

Petrie, S. (2015). “Commodifying” children: The impact of markets in services for children in the United Kingdom. International Journal of Child, Youth and Family Studies, 6(2), 275-294.

Pierson, P. (2000). Increasing returns, path dependence, and the study of politics. American Political Science Review, 94(2), 251-267. http://dx.doi.org/10.2307/2586011

Rachlis, M. (2007). Completing the vision: Achieving the second stage of Medicare. In B. Campbell \& G. P. Marchildon (Eds.), Medicare: Facts, myths, problems and promise (pp. 221-242). Toronto: James Lorimer \& Company Ltd.

Raphael, D. (2010). The health of Canada's children. Part I. Canadian children's health in comparative perspective. Paediatrics and Child Health, 15(1), 23-29.

Raphael, D. (2014). Social determinants of children's health in Canada: Analysis and implications. International Journal of Child, Youth and Family Studies, 5(2), 220-239.

Raphael, D. (2015). The parameters of children's health: Key concepts from the political economy of health literature. International Journal of Child, Youth and Family Studies, 6(2), 186-203.

Rattle, R. (2015). Health impact assessment, municipal development practices, and children's health. International Journal of Child, Youth and Family Studies, 6(2), 308-327.

Teeple, G. (2000). Globalization and the decline of social reform: Into the twenty first century. Aurora, ON: Garamond Press.

Thomas, S., Fayter, D., Misso, K., Ogilvie, D., Petticrew, M., Sowden, A., Whitehead, M. \& Worthy, G. (2008). Population tobacco control interventions and their effects on social inequalities in smoking: Systematic review. Tobacco Control, 17(40), 230-237. http://dx.doi.org/10.1136/tc.2007.023911

Wright, E. O. (1994). The class analysis of poverty. In E. O. Wright (Ed.), Interrogating inequality (pp. 32-50). New York: Verso. 